This article was downloaded by: [b-on: Biblioteca do conhecimento online UP]

On: 13 May 2014, At: 08:16

Publisher: Routledge

Informa Ltd Registered in England and Wales Registered Number: 1072954 Registered

office: Mortimer House, 37-41 Mortimer Street, London W1T 3JH, UK

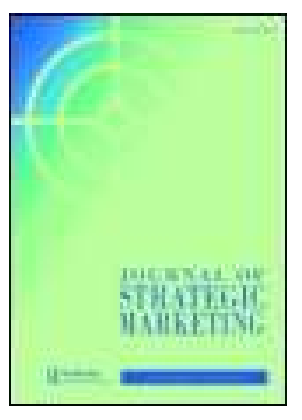

Journal of Strategic Marketing

Publication details, including instructions for authors and subscription information:

http://www.tandfonline.com/loi/rjsm20

\title{
The role of servicescape as a driver of customer value in experience-centric service organizations: the Dragon Football Stadium case
}

\author{
Teresa Fernandes $^{\mathrm{a}}$ \& Sara Neves ${ }^{\mathrm{a}}$ \\ ${ }^{a}$ Faculty of Economics, University of Porto, Porto, Portugal \\ Published online: 06 May 2014.
}

To cite this article: Teresa Fernandes \& Sara Neves (2014): The role of servicescape as a driver of customer value in experience-centric service organizations: the Dragon Football Stadium case, Journal of Strategic Marketing, DOI: 10.1080/0965254X.2014.914058

To link to this article: http://dx.doi.org/10.1080/0965254X.2014.914058

\section{PLEASE SCROLL DOWN FOR ARTICLE}

Taylor \& Francis makes every effort to ensure the accuracy of all the information (the "Content") contained in the publications on our platform. However, Taylor \& Francis, our agents, and our licensors make no representations or warranties whatsoever as to the accuracy, completeness, or suitability for any purpose of the Content. Any opinions and views expressed in this publication are the opinions and views of the authors, and are not the views of or endorsed by Taylor \& Francis. The accuracy of the Content should not be relied upon and should be independently verified with primary sources of information. Taylor and Francis shall not be liable for any losses, actions, claims, proceedings, demands, costs, expenses, damages, and other liabilities whatsoever or howsoever caused arising directly or indirectly in connection with, in relation to or arising out of the use of the Content.

This article may be used for research, teaching, and private study purposes. Any substantial or systematic reproduction, redistribution, reselling, loan, sub-licensing, systematic supply, or distribution in any form to anyone is expressly forbidden. Terms \& Conditions of access and use can be found at http://www.tandfonline.com/page/termsand-conditions 


\title{
The role of servicescape as a driver of customer value in experience-centric service organizations: the Dragon Football Stadium case
}

\author{
Teresa Fernandes* and Sara Neves \\ Faculty of Economics, University of Porto, Porto, Portugal \\ (Received 12 August 2013; accepted 1 February 2014)
}

\begin{abstract}
Service experience is the core of service offering. However, research on the role of the service environment when creating experiences is still underdeveloped, and even less empirical evidence is available that relates servicescape with customers' perceptions of value. Our purpose is to focus on the role of servicescape as a driver of customer experience by analyzing its impact on customer value creation and behavior. We have chosen an experience-centric service organization, a football club, to develop our analysis. A regression analysis was performed to determine the main drivers of value among 'sportscape' components and how it influenced customers' attitude and behavior. A total of 349 questionnaires were collected during a match of the Portuguese Football League at Dragon Stadium. Our analysis showed that servicescape influences consumer perceived value, attitudes, and behavior when creating service experiences: value-in-context generates customers' satisfaction, which in turn has a positive effect on their desire to repeat the experience.
\end{abstract}

Keywords: servicescape; experience; customer behavior; sports; customer value

\section{Introduction}

The physical environment in which the experience is created, the servicescape (Bitner, 1992), is considered a key variable influencing customer perceptions and behavior, and one of the strongest drivers of service value (Walter, Edvardsson, \& Öström, 2010). Services are very engaging when consumed, which accentuates the importance of their surroundings, which can be viewed as an issue for interaction and value co-creation (Edvardsson, Enquist, \& Johnston, 2005; Grönroos \& Ravald, 2011). Besides enabling service operations, servicescapes serve as stimuli themselves, by providing cues (Pine \& Gilmore, 1998) that create, influence, and enable the experience (Sandström, Edvardsson, Kristensson, \& Magnusson, 2008). Servicescapes not only influence the customer' value creation, but also have an impact on their future purchasing and consumption behavior (Pareigis, Echeverri, \& Edvardsson, 2012).

However, research on the role of the service physical environment when creating experiences is still underdeveloped (Hoffman \& Turley, 2002), specially when compared with more interpersonal aspects of the service encounter (Heide \& Gronhaug, 2006; Slåtten, Mehmetoglu, Svensson, \& Sværi, 2009), and even less empirical evidence is available that relates a venue's servicescape with constructs such as perceptions of value and behavioral intentions (Cronin, 2003; Harris \& Ezeh, 2008). Thus, our purpose is to focus on the role of servicescape as a driver of customer experience by analyzing its

*Corresponding author. Email: tfernandes@fep.up.pt 
impact on customer value creation and behavior. We have chosen an experience-centric service organization, a football (soccer) club, to perform our analysis. A regression analysis was performed to determine the main drivers of customer value among 'sportscape' components and how it influenced customers' attitude (satisfaction) and behavior (repurchase). Due to the important role that sporting venue plays in service experience, we expect that servicescape will have impact on customer value creation and repatronage. We end up concluding that servicescape plays a major part in the delivery of the experience and may provide a sustainable competitive advantage if managers develop a better understanding of its role on customer evaluations and behavior.

\section{The role of servicescape as a driver of customer experience}

The concept of service experience has been described as the core of the service offering and, as such, it is a key concept in the emerging paradigm of S-D logic (Vargo \& Lusch, 2004). According to this perspective, value is cocreated with the customer and is realized when a good or service is used, making customer experiences crucial to their perception of value-in-use, rather than embedded in goods or services (Klaus \& Maklan, 2012; Prahalad \& Ramaswamy, 2004; Sandström et al., 2008). Customer experience management has thus become a crucial element for developing and sustaining customer satisfaction and loyalty (Chakravorti, 2011).

According to Gupta and Vajic (1999), an experience occurs when a customer has a sensation or knowledge acquisition resulting from interaction with the different dimensions of a context created by a service provider, across multiple touchpoints (Meyer \& Schwager, 2007). Clues are the touchpoints of service experiences (Berry, Shankar, Parish, Cadwallader, \& Dotzel, 2006). Companies need to embed, execute, and manage these clues to create the desired thoughts and feelings in consumers (Chakravorti, 2011). Managing customer experiences entails the careful management of many clues, and among them the physical environment in which the experience is created is often considered a key variable and one of the strongest drivers of service value (Martin-Ruíz, Barroso-Castro, \& Rosa-Diáz, 2012; Walter et al., 2010).

Throughout time, several researchers have used various terms to indicate 'environment,' reflecting the eclectic nature of the literature in the area (Harris \& Ezeh, 2008). It is commonly accepted that the term 'environment' was first used by Kotler (1973) in his article 'Atmospheric as a Marketing Tool' in which the author defines it as the conscious design of the space in order to create certain emotions on the customer and thereby lead to an increased likelihood of purchase. However, servicescape is the term more commonly known, and was defined as the environment in which the service is assembled and where the seller and the customer interact, in combination with the tangible products that facilitate the performance or communication of the service' (Bitner, 1992). The concept was introduced in the literature by Mary Jo Bitner in 1992 and was the result of the combination of two English words, service and landscape, in order to describe the artificial setting of the surrounding facilities' services.

Given services' intangibility, customer trust is often supported on visible and tangible cues (Zeithaml, Parasuraman, \& Berry, 1985). This tangible evidence may eventually affect the evaluation that a customer does of the service encounter, given that the physical environment offers a 'visual metaphor of the total supply of an organization,' by the proposal 'of the potential usage and quality of service' (Bitner, 1992). The servicescape influences the customers' perceptions, it provides clues throughout the meeting, it creates memories in the mind of the customer (Bitner, 1990; Reimer \& Kuehn, 2005), and it may 
serve to create expectations about the price and quality of the service (Bebko, Sciulli, \& Garg, 2006). The servicescape can also entertain or distract the customer, thereby influencing their sense of time (Baker \& Cameron, 1996; Berry et al., 2006) and have an effect on the evaluation of intangible aspects such as trust and empathy (Reimer \& Kuehn, 2005). Therefore, it creates emotions and changes the state of mind through the sensory qualities of the environment (Baker \& Cameron, 1996; Berry et al., 2006; Le Bel, 2005), influencing personal interactions among customers and between them and the employees (Le Bel, 2005), and affecting future intentions of repatronage (Berry et al., 2006; Carbone \& Haekel, 1994). Servicescapes are particularly important in environments where there is limited or no interaction with employees and the customer spends considerable time (Hightower, Brady, \& Baker, 2002). Servicescapes not only influence the customer' value creation, but also have an impact on their future purchasing and consumption behavior (Pareigis et al., 2012).

This is particularly true in experience-centric service organizations (Voss, Roth, \& Chase, 2008). Experience-centric service organizations deliver services in which the customer experience is at the core of service offering. Since experiences are constructed by customers and cannot be fully controlled by organizations, experience-centric service providers stage the prerequisites which enable customers to have the desired experiences (Edvardsson \& Olsson, 1996), namely the central activity of the experience and the context in which it takes place (including the servicescape). Consumption of experiencecentric services is more likely driven by emotional than utilitarian reasons. Satisfaction is more influenced by the excitement and stimulation of the experience than by the perceived quality of the core service rendered. Experience-centric services are atmospheric dominant, since the consumer may purposely attend the service to experience the environment and the ambience. The design of experience-centric services involves designing a series of cues. The collection of tangible service elements, specifically the physical environment in which a service is delivered is therefore vital to the creation of compelling service experiences (Hoffman \& Turley, 2002). In these services, situational involvement may be more influential than the service itself, turning servicescape into a focal point in the delivery of customer delight and quality service experiences.

Chelladurai and Chang (2000) define quality as the ability to delight customers and to satisfy their needs. However, it is known that the supply of services involves human perceptions and expectations, making thereby the definition and measurement of their quality into a complex and difficult task (Brady \& Cronin, 2001). Parasuraman, Zeithaml, and Berry (1988) define service quality as a perceived judgment about an entity's overall excellence or superiority, positing service quality as an antecedent of perceived value and of outcomes such as repeat purchase. This definition is based on a comparison between the quality of service perceived prior to consumption and the perception of performance after service delivery (Grönroos, 1982; Parasuraman, Zeithaml, \& Berry, 1985). However, since physical environments play a large part in experience-centric services, this may be an incorrect way to measure quality in experiential services. Voss et al. (2008) claim that the traditional concept of service quality focuses largely on transaction specific assessment, rather than on the sequence of touchpoints with the firm in buying and obtaining the service (including the servicescape) that constitutes customer experience.

Researchers link service quality to consumer behavior either directly or indirectly via customer satisfaction (Klaus \& Maklan, 2012). Oliver (1997) argues that satisfaction is a customer response, a post-purchase phenomenon that portrays how much the customer likes or dislikes the service (Churchill \& Surprenant, 1982), thus being an attitude that 
results from a comparison between expectations and the perceived performance of the service (Oliver, 1980). The judgment of customer satisfaction or dissatisfaction depends on how customers perceive the result obtained when compared with what they expected to receive (Millán \& Esteban, 2004). Burns, Graefe, and Absher (2003) describe disconfirmation as the event when perceived performance is lower than expectations. Confirmation, in turn, is when the perceived performance is greater than expectations. It is more likely that the customer will be satisfied when there is confirmation (Rust, Zahorik, \& Keiningham, 1995), and a satisfied customer with multiple service encounters will in the long term develop a positive perception of the overall quality of the company (Parasuraman et al., 1988). Researchers suggest that service quality drives satisfaction, which in turn drives behavior (Shankar, Smith, \& Rangaswamy, 2003). As indicators of the quality of the service experience, servicescapes may have a strong influence on customers' loyalty intentions (e.g., repatronage) in a range of contexts (Cronin, 2003; Foxall \& Yani-de-Soriano, 2005), namely experiential services.

\section{Research framework and methodology}

Our purpose is to focus on service experience and servicescape, by analyzing its impact on customer value creation. We have chosen an experience-centric service organization, a football (soccer) club, to perform our analysis. Football clubs provide a good opportunity to study customers' interaction with servicescape in an experiential context. Consumption of sporting events is mainly driven by emotional reasons and spectators are likely to be highly involved with the service encounter and atmosphere of the place, including the layout, aesthetic, and functional aspects of the servicescape. Since there are uncontrollable factors associated with the football match (e.g., team performance) that influence the customer experience, football clubs must actively manage the physical environment (the 'sportscape') in order to excel. Also, few or no employees are present and spectators interact with facilities for an extended period of time.

Based on the work of Wakefield and Blodgett (1996), our research focuses on the servicescape as a driver of service experience and measures outcomes through quality, satisfaction, and repurchase intention. According to literature review, we propose the following research framework and hypothesis (Figure 1).

Layout accessibility refers to the way in which furnishings and equipment, service areas, and hallways are organized (Bitner, 1992). An effective layout will provide an easy entry and exit, and will make ancillary service areas such as concessions, restrooms, and souvenir stands easier to get into (Wakefield \& Blodgett, 1996).

Facility aesthetics refers to interior design and decoration, which contribute to the attractiveness of the servicescape. Customers tend to evaluate the attractiveness of the place when they approach it, even outside of it. Once inside, customers of leisure services spend hours examining (consciously and unconsciously) the venue (Wakefield \& Blodgett, 1994).

The third factor, seating comfort, is associated with the degree of physical comfort. This factor, as a servicescape dimension, represents a nonverbal communication between the customer and the servicescape (Lam, Chan, Fong, \& Lo, 2011) and is particularly relevant to those customers who remain seated for a long number of hours (Wakefield \& Blodgett, 1996).

On the other hand, electronic equipment can be used to improve the customer experience. High-quality scoreboards projecting instant replays scores or information about players are able to make the waiting times more pleasant and add emotion for the spectator. Finally, the cleaning factor is also of particular importance, mostly in situations 


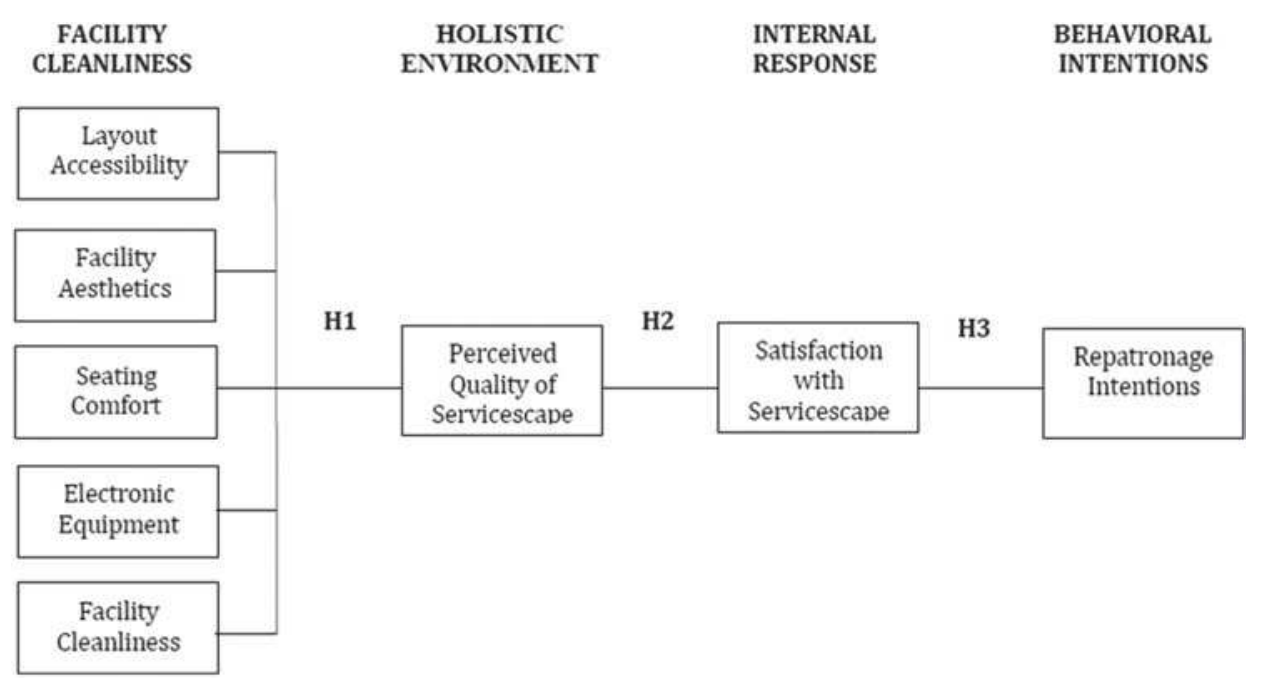

Figure 1. Research model.

where the customers remain in the facility for several hours, as they tend to implicitly associate cleanliness with the quality of the service (Wakefield \& Blodgett, 1996). Barber and Scarcelli (2010) conclude that customers tend to select, stay, and return to a service depending on the perceived degree of cleanliness.

Perceived quality was measured with three items that portray the perceptions of the customers (terrible - great), the expectations (much worse than I expected - much better than I expected), and the standards (not at all what it should be - just what it should be) as suggested by Fornell (1992), and as Wakefield and Blodgett (1996) did. We thus propose that:

Hypothesis 1: The servicescape dimensions (layout accessibility, facility aesthetics, seating comfort, electronic equipment, and facility cleanliness] will have a positive effect on the perceived quality of the servicescape.

Several studies demonstrate the influence of the physical environment on the perception of service quality and on customer satisfaction (Bitner, 1990; Hightower et al., 2002; Le Bel, 2005; Le Blanc, 1992; Park, Robertson, \& Wu, 2005; Swan, Richardson, \& Hutton, 2003; Van Pham \& Simpson, 2006; Wakefield \& Blodgett, 1996; Young, Cunningham, \& Lee, 1994). It is therefore important to know how the sequence servicescape - quality - satisfaction works. Thus, we propose that:

Hypothesis 2: Perceived quality of the servicescape will have a positive effect on satisfaction.

Finally, one can say that all customers visit a service company with a purpose or a goal, which can be strengthened or harmed by the servicescape (Bitner, 1992). As a result, perceptions of physical environments can affect and constrain satisfaction and, in a roundabout way, the intention or not to return (Berry et al., 2006; Le Bel, 2005), and so we expect that:

Hypothesis 3: Satisfaction will have a positive effect on repatronage intention. 
Each question was created on the existing literature in the field of sports management and marketing services. With the exception of the initial questions regarding the characteristics of the spectators and the frequency of their visits, all the other variables were applied based on the research of Wakefield and Blodgett (1996) and Wakefield, Blodgett, and Sloan (1996). The focus of the investigation covers only the environment that can be controlled. Thus, all physical evidence that is outside, including the parking lot and access to the stadium, were not included. The spectator's satisfaction was also measured in accordance with Wakefield and Blodgett (1996), with one item from Cronin and Taylor (1994) and another from Bitner (1992). Finally, to assess the repatronage intention to the stadium, individuals were asked about their willingness to attend matches in the future, the same way it was done in Cronin and Taylor (1994), Wakefield and Sloan (1995), Wakefield and Blodgett (1996), Wakefield et al. (1996), and Hill and Green (2000) studies.

A regression analysis was performed to determine the main drivers of customer value among 'sportscape' components (namely layout accessibility, aesthetics, comfort, cleanliness, and electronic equipment) and how it influenced customers' attitude (satisfaction) and behavior (repurchase). A total of 368 questionnaires were collected on a random basis during a match of the Portuguese Professional Football League 2011/2012 among spectators at the Dragon Stadium. The data collection was similar to a mall-intercept method, with respondents filling out the questionnaire on site in order to better measure value-in-use or value-in-context. After validation, data collection resulted in 349 usable responses.

\section{Data analysis and discussion of results}

From the 349 validated questionnaires, 18 belonged to fans of the visiting team. So to study the relationships between the variables, it was decided to work only with the remaining 331 questionnaires. The majority of individuals (74.3\%) were male, and only $25.7 \%$ are female. The proportion obtained in our study is similar to that of Dhurup and Mofoka (2011), 73\% male and 27\% female. With regard to ages, we observed that the average is approximately 38 years, and that nearly $60 \%$ of the sample was aged up to 39 years old. We can observe from Table 1 that the different percentages are very close to each other, showing somehow that sport is a transversal phenomenon. The minimum age was 18 years old, a requirement for the quiz, and the highest was 84 years old.

The frequency of visits to the Dragon Stadium shows that 29.3\% of those surveyed went 3 times in the last 6 months, 20.8\% went $4-6$ times, $7.6 \%$ were $7-9$ times, and finally with the largest percentage those who have visited the stadium more than 10 times with $40.2 \%$. The two groups with a higher representation are precisely the ones on both ends, either going very few times or going frequently.

Table 1. Descriptive statistics for the spectators age.

\begin{tabular}{lcccc}
\hline Age & Frequency & Percent & Valid percent & Cumulative percent \\
\hline$<20$ years & 50 & 15.1 & 15.7 & 15.7 \\
$20-29$ & 80 & 24.2 & 25.2 & 40.9 \\
$30-39$ & 56 & 16.9 & 17.6 & 58.5 \\
$40-49$ & 53 & 16.0 & 16.7 & 75.2 \\
$50-59$ & 38 & 11.5 & 11.9 & 100 \\
$\geq 60$ & 41 & 12.4 & 12.9 & \\
Missing & 13 & 3.9 & 100 & \\
Total & 331 & 100 & & \\
\hline
\end{tabular}


The analysis starts with a factor analysis to servicescape, quality, and satisfaction dimensions. Multiple linear regression analysis was performed between the dimensions of servicescape and quality, and then a simple linear regression analysis between quality and satisfaction. Last, a Pearson correlation was performed between satisfaction and repatronage intention. The validity of the scales was made through analysis of Cronbach's alpha, which indicates the degree of reliability.

We have conducted an exploratory factorial analysis by the method of principal component analysis using Varimax rotation for servicescape, quality, and satisfaction variables (Table 2). With a value of Kaiser-Meyer-Olkin (KMO) equal to 0.888, considered as good and Bartlett's test with a $p$-value $<0.001$, it leads to the rejection of the null hypothesis, therefore indicating that there is a significant correlation between the variables and the data are appropriate for a factorial analysis. At the end of the analysis, for the servicescape variable we identified five components with eigenvalues above 1 , suggesting five factors composed by 20 variables, with a total variance explained of $72.43 \%$; one factor for the three quality items with an explained variance of $66.21 \%$; and one factor for satisfaction with $83.01 \%$ variance explained.

Hypothesis 1 aims to determine to what extent the quality perceived by the spectators (dependent variable) is explained by the variables that belong to the servicescape, in particular layout accessibility, facility aesthetics, seating comfort, electronic equipment, and facility cleanliness (independent variables). Thereby we proceed to multiple linear regression analysis, a statistical technique used to analyze the relationship between a single dependent variable and several independent variables (Hair, Anderson, Tatham, \& Black, 1998). $35.5 \%$ (adjusted $R^{2}$ ) of the variability of the perceived quality of servicescape is explained by the variables of servicescape. The analysis of the simple correlation coefficient $(R=0.604)$ suggests that there is a high positive correlation $(R>0.6)$ between the variables (Table 3$)$.

Hypothesis 2 was also supported (Table 4). By analyzing the simple correlation coefficient $(R=0.482)$, we verified that there is a good positive correlation $(R>0.4)$ between the variables. The adjusted coefficient of determination (adjusted $R^{2}=0.230$ ) suggests that $23.0 \%$ of the variability of the dependent variable satisfaction is explained by the independent variable quality.

Similar to Hypotheses 1 and 2, Hypothesis 3 was also supported. Repatronage intention consists of a single variable, making therefore a principal component analysis impossible to perform as it was in the case of the other dimensions. Thus, the hypothesis that satisfaction positively influences the return of the spectator is tested by a Pearson correlation between the factor satisfaction and the variable 'In the future, their presence in the games in this stadium will be Not Frequent/Very Frequent).' The satisfaction of the spectators has an influence, although small $(R=0.201)$ in the predisposition to return to the stadium to watch a football match, so we can say that an increase in spectator satisfaction has a positive effect on its return to the stadium.

\section{Research and managerial contributions}

Our analysis showed that servicescape influences consumer perceived value when creating service experiences, with comfort and layout accessibility as the main drivers, followed by cleanliness, electronic equipment, and finally the aesthetic dimension. However, despite being considered as the main driver, comfort received the lowest evaluation of the five factors, while the least important driver, aesthetics, was the best-rated factor by spectators. The results suggest that experience-centric services like football clubs, where the consumer 
Table 2. Rotative component matrix.

\begin{tabular}{|c|c|c|c|c|c|}
\hline & & & ompone & & \\
\hline & 1 & 2 & 3 & 4 & 5 \\
\hline Servicescape & & & & & \\
\hline $\begin{array}{l}\text { Signs at this stadium give clear directions of where } \\
\text { things are located }\end{array}$ & 0.772 & 0.174 & 0.379 & 0.044 & 0.059 \\
\hline Signs at this stadium help me know where I am going & 0.726 & 0.122 & 0.404 & 0.079 & 0.048 \\
\hline $\begin{array}{l}\text { Overall, this facility layout makes it easy to get where } \\
\text { you want to go }\end{array}$ & 0.705 & 0.228 & 0.142 & 0.169 & 0.182 \\
\hline The facility layout makes it easy to get to the restrooms & 0.670 & 0.230 & 0.058 & 0.281 & 0.079 \\
\hline The facility layout makes it easy to get to your seat & 0.597 & 0.244 & 0.027 & 0.219 & 0.342 \\
\hline $\begin{array}{l}\text { The facility layout makes it easy to get to the food } \\
\text { service areas }\end{array}$ & 0.594 & 0.208 & 0.086 & 0.284 & 0.215 \\
\hline This facility maintains clean walkways and exits & 0.267 & 0.865 & 0.084 & 0.160 & 0.101 \\
\hline Overall, this facility is kept clean & 0.229 & 0.851 & 0.131 & 0.180 & 0.189 \\
\hline This facility maintains clean food service areas & 0.177 & 0.846 & 0.193 & 0.160 & 0.159 \\
\hline This facility maintains clean restrooms & 0.203 & 0.825 & 0.221 & 0.106 & 0.100 \\
\hline The scoreboards are entertaining to watch & 0.192 & 0.086 & 0.822 & 0.193 & 0.138 \\
\hline The scoreboards add excitement to the place & 0.139 & 0.137 & 0.811 & 0.216 & 0.023 \\
\hline The scoreboards provide interesting statistics & 0.191 & 0.123 & 0.809 & 0.115 & 0.109 \\
\hline This facility has high-quality scoreboards & 0.159 & 0.266 & 0.643 & 0.133 & 0.208 \\
\hline The seat arrangements provide plenty of space & 0.239 & 0.182 & 0.234 & 0.803 & 0.098 \\
\hline There is plenty of knee room in the seats & 0.192 & 0.122 & 0.185 & 0.785 & 0.078 \\
\hline This facility provides comfortable seats & 0.195 & 0.193 & 0.181 & 0.749 & 0.132 \\
\hline This is an attractive facility & 0.144 & 0.217 & 0.160 & 0.131 & 0.888 \\
\hline This facility's architecture gives it an attractive character & 0.135 & 0.189 & 0.080 & 0.080 & 0.884 \\
\hline $\begin{array}{l}\text { This facility is painted in attractive colors } \\
\text { Ouality }\end{array}$ & 0.408 & 0.015 & 0.248 & 0.108 & 0.559 \\
\hline $\begin{array}{l}\text { The overall quality of this facility is: much worse than I } \\
\text { expected - much better than I expected }\end{array}$ & 0.851 & & & & \\
\hline $\begin{array}{l}\text { The overall quality of this facility is: not at all what it } \\
\text { should be - just what it should be }\end{array}$ & 0.837 & & & & \\
\hline $\begin{array}{l}\text { The overall quality of this facility is: terrible - great } \\
\text { Satisfaction }\end{array}$ & 0.750 & & & & \\
\hline $\begin{array}{l}\text { The overall feeling I get from this facility: puts me in a } \\
\text { bad mood - puts me in a good mood }\end{array}$ & 0.911 & & & & \\
\hline $\begin{array}{l}\text { The overall feeling I get from this facility: is } \\
\text { dissatisfaction - is satisfaction }\end{array}$ & 0.911 & & & & \\
\hline
\end{tabular}

Note: Extraction method: principal component analysis. Rotation method: Varimax with Kaiser normalization.

spends extended period of times, should not only focus on appealing design, but also guarantee that seating arrangements and spatial layouts are designed in order to allow comfortable and free exploration of the service experience. We have found that servicescape also influences consumer attitudes and behavior: value-in-context generates customers' satisfaction, which in turn has a positive effect on their desire to repeat the experience.

This study makes several theoretical and research contributions. The findings contribute to S-D logic through focus on customer experience and interactions with servicescape, resulting in value-in-use or value-in-context. Although intertwined, the research on these concepts is relatively new and undeveloped (Hoffman \& Turley, 2002), since the majority of service research focus more the interpersonal nature of the encounter and relational elements in the experience environment (Heide \& Gronhaug, 2006; Slåtten et al., 2009). Also, even less empirical evidence is available about the impact of 
Table 3. Regression analyses between the servicescape variables and quality.

\begin{tabular}{|c|c|c|c|c|c|}
\hline & $R$ & $R^{2}$ & Adjusted $R^{2}$ & Durbin-Watson & \\
\hline & 0.604 & 0.365 & 0.355 & 2.133 & \\
\hline ANOVA & Sum of squares & df & Mean square & $F$ & Sig. \\
\hline Regression & 109.454 & 5 & 21.891 & 34.743 & 0.000 \\
\hline Residual & 190.282 & 302 & 0.63 & & \\
\hline Total & 299.736 & 307 & & & \\
\hline Coefficients & $B$ & Std. error & $\beta$ & $T$ & Sig. \\
\hline (Constant) & 0.014 & 0.045 & & 0.303 & 0.762 \\
\hline Accessibility & 0.321 & 0.045 & 0.325 & 7.088 & 0.000 \\
\hline Aesthetics & 0.168 & 0.045 & 0.170 & 3.716 & 0.000 \\
\hline Comfort & 0.363 & 0.045 & 0.367 & 8.008 & 0.000 \\
\hline Electronic equip. & 0.206 & 0.045 & 0.208 & 4.541 & 0.000 \\
\hline Cleanliness & 0.226 & 0.045 & 0.229 & 4.992 & 0.000 \\
\hline
\end{tabular}

Note: (1) Predictors: (constant), ACCESS, AESTHE, COMFO, EQUIP, CLEAN. (2) Dependent: QUALID.

servicescape in customer purchase decisions (Cronin, 2003), such as repatronage. Finally, most empirical research concerning the servicescape focuses on one environmental element only (Harris \& Ezeh, 2008) and considers the provider's point of view. This study focuses the customer experience of the physical environment as a whole and analyses experience drivers from the customer's point of view, providing a better understanding of customer value creation.

On a managerial level, and given the vast array of choices available to customers, managing customer experiences has been found an increasingly importance practice to differentiate service offerings. Today's firms are competing with experiences (Berry, Carbone, \& Haeckel, 2002). Namely, sport organizations are facing intense competition, not only from other sports but also from a wide range of other leisure services (Shilbury \& Westerbeek, 1996). Thus, sports organizations should strive for customers' preference (Greenwell, 2001). It is also true that sports organizations realized that the game can also be played outside the 'four lines,' meaning their attention is now focused on the implementation of strategies that increase the attendance of spectators in their sports venues. Servicescape plays a major part in the delivery of the experience and may provide a sustainable competitive advantage if managers develop a more systematic approach to cue placement and a better understanding of its role on customer evaluations and behavior. In the special case of experience-centric services like football clubs and other sporting events, where the core service is particularly difficult to control (e.g., the players'

Table 4. Regression analysis between quality and satisfaction.

\begin{tabular}{lccccl}
\hline & $R$ & $R^{2}$ & Adjusted $R^{2}$ & Durbin-Watson & \\
\hline ANOVA & Sum of squares & df & Mean square & 1.889 & Sig. \\
Regression & 76.454 & 1 & 76.454 & 99.022 & 0.000 \\
Residual & 252.474 & 327 & 0.772 & & \\
Total & 328.929 & 328 & & & Sig. \\
Coefficients & $B$ & Std. error & $\beta$ & 0.017 & 0.987 \\
(Constant) & 0.001 & 0.048 & & 9.951 & 0.000 \\
Quality & 0.483 & 0.049 & 0.482 & &
\end{tabular}

Note: (1) Predictors: (constant), QUALID. (2) Dependent: SATISF. 
performance, the outcome of the game, the quality of the teams, and even the quality of the game itself), organizations should manage properly controllable aspects of the servicescape. Since the place of consumption has a strong impact on customer perceptions regarding the service experience, sport managers are able to work with some environmental dimensions like comfort and layout, in order to add value to customers and influence repatronage in a more entertainment-oriented market. Consequently, we consider it critical to develop improved and increased studies, taking into account that empirical research in the area is still underdeveloped.

\section{Limitations and future research}

This study adds to the growing body of literature on servicescape by exploring the concept applied to the area of sports entertainment, where studies are still limited. Though the study is developed in a specific context, findings can be adapted to other service settings and provide a 'starting point' that future research should extend and further refine. The following gives a list of future directions:

- Within sport organizations, future studies could compare the role of the central activity of the experience (the core service, e.g., the football game) and the context in which it takes place (the servicescape) in driving customer value. Madrigal (1995) concluded that some attributes of the game have contributed to the enjoyment of the spectator. Tomlinson, Buttle, and Moores (1995) have concluded that both dimensions are important for the spectators, and that the servicescape was regarded as the most important in contrast with the core service.

- Other research opportunity exists in the analysis of the fanaticism and loyalty to the soccer club. Although the servicescape dimensions influence the spectators, it is likely that some loyal supporters will return to the stadium more for its loyalty to the club than because the perceived quality of the servicescape (Lee, Ryder, \& Shin, 2003).

- It is also reasonable to assume that customers' experiences of physical surroundings in sports and other experience-centric services are able to evoke customers' feelings and emotions. However, there is still a lack of empirical investigations linking the two concepts.

- Also, the effect on sales profit may be further studied. Positive perceptions upon the physical environment influence customers' desire to stay, return, and spend money (Mehrabian \& Russell, 1974). Hui and Bateson (1991) showed that pleasant environments lead to longer stays and that a longer stay in the facility can mean higher sales profits beyond ticket sale.

- Finally, Uhrich and Benkenstein (2011) research found that positive perceptions of other customers, the density, their appearance, and their behavior can influence the response of customers to the environment. The service offered in leisure services is usually delivered to customers who are sharing the same service setting. The effect of people, either other customers or employees, can change the perception of quality. Nevertheless, this social dimension was left out and might produce a new research in the future.

\section{Conclusion}

S-D logic conceives services, including servicescapes, as an issue for interaction and value cocreation. Our analysis showed that servicescape influences consumer perceived value 
when creating service experiences, with comfort and layout accessibility as the main drivers, followed by cleanliness, electronic equipment, and finally the aesthetic dimension. We have found that servicescape also influences consumer attitudes and behavior: valuein-context generates customers' satisfaction, which in turn has a positive effect on their desire to repeat the experience. Though research on the role of service physical environment when creating experiences is still underdeveloped, servicescape has a major influence, namely in experience-centric organizations where experiences are constructed by customers and cannot be fully controlled and atmosphere is dominant (like in sport clubs and leisure services in general). We also must point out that today's customers have at their disposal an extremely wide range of leisure services, a fact that became progressively more challenging for service providers. In this way, managers should create a value-added service in order to achieve customer preference. Our purpose is to provide guidance to sports managers to increase competitive advantage through servicescape.

\section{References}

Baker, J., \& Cameron, M. (1996). The effects of the service environment on affect and consumer perception of waiting time: An integrative review and research propositions. Journal of the Academy of Marketing Science, 24, 338-349.

Barber, N., \& Scarcelli, J. (2010). Enhancing the assessment of tangible service quality through the creation of a cleanliness measurement scale. Managing Service Quality, 20, 70-88.

Bebko, C., Sciulli, L., \& Garg, R. (2006). Consumers' level of expectation for services and the role of implicit service promises. Services Marketing Quarterly, 28(2), 1-23.

Berry, L., Carbone, L., \& Haeckel, S. (2002). Managing the total customer experience. Sloan Management Review, 43, 85-88.

Berry, L., Shankar, V., Parish, J., Cadwallader, S., \& Dotzel, T. (2006). Creating new markets through service innovation. MIT Sloan Management Review, 47, 56-63.

Bitner, M. (1990). Evaluating service encounters: The effects of physical surroundings and employee responses. Journal of Marketing, 54, 69-82.

Bitner, M. (1992). Servicescapes: The impact of physical surroundings on customers and employees. Journal of Marketing, 56, 57-71.

Brady, M., \& Cronin, J. (2001). Some new thoughts on conceptualizing perceived service quality: A hierarchical approach. Journal of Marketing, 65, 34-49.

Burns, R., Graefe, A., \& Absher, J. (2003). Alternate measurement approaches to recreational customer satisfaction: Satisfaction-only versus gaps scores. Leisure Sciences, 25, 363-380.

Carbone, L., \& Haekel, S. (1994). Relationship engineering customer experiences. Journal of Marketing Management, 3, 8-19.

Chakravorti, S. (2011). Managing organizational culture change and knowledge to enhance customer experiences: Analysis and framework. Journal of Strategic Marketing, 19, 123-151.

Chelladurai, P., \& Chang, K. (2000). Targets and standards of quality in sport services. Sport Management Review, 3, 1-22.

Churchill, G., \& Suprenant, C. (1982). An investigation into the determinants of customer satisfaction. Journal of Marketing Research, 19, 491-504.

Cronin, J. (2003). Looking back to see forward in services marketing: Some ideas to consider. Journal of Marketing, 54, 5-131.

Cronin, J., \& Taylor, S. (1994). SERVPERF versus SERVQUAL: Reconciling performance-based and perceptions-minus-expectations measurement of service quality. Managing Service Quality, $13,332-337$.

Dhurup, M., \& Mofoka, M. (2011). A factor analytical study of the dimensions of sportscapes in selected soccer stadia in Gauteng, South Africa. African Journal for Physical, Health Education, Recreation and Dance, 17.

Edvardsson, B., \& Olsson, J. (1996). Key concepts for new service development. The Service Industries Journal, 16, 140-164.

Edvardsson, B., Enquist, B., \& Johnston, R. (2005). Co-creating customer value through hyperreality in the pre-purchase service experience. Journal of Service Research, 8, 149-161. 
Fornell, C. (1992). A national customer satisfaction barometer: The Swedish experience. Journal of Marketing, 56, 6-21.

Foxall, G., \& Yani-de-Soriano, M. (2005). Situational influence on consumers' attitude and behaviour. Journal of Business Research, 46, 149-158.

Greenwell, C. (2001). The influence of spectator sports facilities on customer satisfaction and profitability. Dissertation presented in Partial Fulfillment of the Requirements for the Degree Doctor of Philosophy in the Graduate School of The Ohio State University.

Grönroos, C. (1982). Strategic management and marketing in the service sector. Helsingfors: Research Reports, Swedish School of Economics and Business Administration.

Grönroos, C., \& Ravald, A. (2011). Service as business logic: Implications for value creation and marketing. Journal of Service Management, 22, 5-22.

Gupta, S., \& Vajic, M. (1999). The conceptual and dialectic nature of experiences. In J. Fitzsimmons \& M. Fitzsimmons (Eds.), New service development (pp. 33-51). Thousand Oaks, CA: Sage.

Hair, J., Anderson, R., Tatham, R., \& Black, W. (1998). Multivariate data analysis. Upper Saddle River, NJ: Prentice Hall.

Harris, L., \& Ezeh, C. (2008). Servicescape and loyalty intentions: An empirical investigation. European Journal of Marketing, 42, 390-422.

Heide, M., \& Gronhaug, K. (2006). Atmosphere: Conceptual issues and implications for hospitality management. Scandinavian Journal of Hospitality and Tourism, 6, 271-286.

Hightower, R., Brady, M., \& Baker, T. (2002). Investigating the role of the physical environment in hedonic service consumption: An exploratory study of sporting events. Journal of Business Research, 55, 697-707.

Hill, B., \& Green, B. (2000). Repeat attendance as a function of involvement, loyalty, and the sportscape across three football contexts. Sport Management Review, 3, 145-162.

Hoffman, K., \& Turley, L. (2002). Atmospherics, service encounters and consumer decision making: An integrative perspective. Journal of Marketing Theory and Practice, 10, 33-47.

Hui, M., \& Bateson, J. (1991). Perceived control and the effects of crowding and consumer choice on the service experience. Journal of Consumer Research, 18, 174-184.

Klaus, P., \& Maklan, S. (2012). EXQ: A multiple-item scale for assessing service experience. Journal of Service Management, 23, 5-33.

Kotler, P. (1973). Atmospherics as a marketing tool. Journal of Retailing, 49, 48-64.

Lam, L., Chan, K., Fong, G., \& Lo, F. (2011). Does the look matter? The impact of casino servicescape on gaming customer satisfaction, intention to revisit, and desire to stay. International Journal of Hospitality Management, 30, 558-567.

Le Bel, J. (2005). Beyond the friendly skies: An integrative framework for managing the air travel experience. Managing Service Quality, 15, 437-451.

Le Blanc, G. (1992). Factors affecting customer evaluation of service quality in travel agencies: An investigation of customer perceptions. Journal of Travel Research, 30, 10-16.

Lee, S., Ryder, C., \& Shin, H. J. (2003). An investigation of environmental motivation factors affecting fans of minor league baseball. The Sport Journal, 6.

Madrigal, R. (1995). Cognitive and affective determinants of fan satisfaction with sporting event attendance. Journal of Leisure Research, 27, 205-222.

Martin-Ruíz, D., Barroso-Castro, C., \& Rosa-Diáz, I. (2012). Creating customer value through service experiences: An empirical study in the hotel industry. Tourism and Hospitality Management, 18, 37-53.

Mehrabian, A., \& Russell, J. (1974). An approach to environmental psychology. Cambridge: MIT Press.

Meyer, C., \& Schwager, A. (2007). Understanding customer experience. Harvard Business Review, $85,117-126$.

Millán, À., \& Esteban, Á. (2004). Development of a multiple-item scale for measuring customer satisfaction in travel agencies services. Tourism Management, 25, 533-546.

Oliver, R. (1980). A cognitive model of the antecedents and consequences of satisfaction decisions. Journal of Marketing Research, 17, 460-469.

Oliver, R. (1997). Satisfaction: A behavioral perspective on the consumer. New York, NY: McGraw-Hill.

Parasuraman, A., Zeithaml, V., \& Berry, L. (1985). A conceptual model of service quality and its implications for future research. Journal of Marketing, 49, 41-50. 
Parasuraman, A., Zeithaml, V., \& Berry, L. (1988). SERVQUAL: A multiple-item scale for measuring customer perceptions of service quality and its implications for future research. Journal of Retailing, 64, 12-40.

Pareigis, J., Echeverri, P., \& Edvardsson, B. (2012). Exploring internal mechanisms forming customer servicescape experiences. Journal of Service Management, 23, 677-695.

Park, J., Robertson, R., \& Wu, C. (2005). Investigating the effects of airline service quality on airline image and passengers' future behavioral intentions: Findings from Australian international air passengers. The Journal of Tourism Studies, 16, 2-11.

Pine, J., \& Gilmore, J. (1998). Welcome to the experience economy. Harvard Business Review, 76, $97-105$.

Prahalad, C., \& Ramaswamy, V. (2004). Co-creation experiences: The next practice in value creation. Journal of Interactive Marketing, 18, 5-14.

Reimer, A., \& Kuehn, R. (2005). The impact of servicescape on quality perception. European Journal of Marketing, 39, 785-808.

Rust, R., Zahorik, A., \& Keiningham, T. (1995). Return on quality (ROQ): Making service quality financially accountable. Journal of Marketing, 59, 58-70.

Sandström, S., Edvardsson, B., Kristensson, P., \& Magnusson, P. (2008). Value in use through service experience. Managing Service Quality, 18, 112-126.

Shankar, V., Smith, A., \& Rangaswamy, A. (2003). Customer satisfaction and loyalty in online and offline environments. International Journal of Research in Marketing, 20, 153-175.

Shilbury, D., \& Westerbeek, H. (1996). Measuring service quality: A study of Victorian based NBL teams. Paper presented at the 2nd Annual Sport Management Association of Australia and New Zealand Conference, Southern Cross University, Lismore.

Slåtten, T., Mehmetoglu, M., Svensson, G., \& Sværi, S. (2009). Atmospheric experiences that emotionally touch customers - A case study from a winter park. Managing Service Quality, 19, $721-746$.

Swan, J., Richardson, L., \& Hutton, J. (2003). Do appealing hospital rooms increase patient evaluations of physicians, nurses, and hospital services? Health Care Management Review, 28, $254-264$.

Tomlinson, M., Buttle, F., \& Moores, B. (1995). The fan as a customer: Customer service in sports marketing. Sport Marketing Quarterly, 3, 19-33.

Uhrich, S., \& Benkenstein, M. (2011). Physical and social atmospheric effects in hedonic service consumption: Customers' roles at sporting events. Service Industries Journal, iFirst Article, 1-17.

Van Pham, K., \& Simpson, M. (2006). The impact of frequency of use on service quality expectations: An empirical study of trans-Atlantic airline passengers. Journal of American Academy of Business, 10(1), 1-6.

Vargo, S., \& Lusch, R. (2004). Evolving to a new dominant logic for marketing. Journal of Marketing, 68, 1-17.

Voss, C., Roth, A., \& Chase, R. (2008). Experience, service operations strategy, and services as destinations: Foundations and exploratory investigation. Production and Operations Management, 17, 247-266.

Wakefield, K., \& Blodgett, J. (1994). The importance of servicescapes in leisure service settings. Journal of Service Marketing, 8, 66-76.

Wakefield, K., \& Blodgett, J. (1996). The effect of the servicescape on customers' behavioral intentions in leisure service settings. Journal of Services Marketing, 10, 45-61.

Wakefield, K., Blodgett, J., \& Sloan, H. (1996). Measurement and management of the sportscape. Journal of Sport Management, 10, 15-31.

Wakefield, K., \& Sloan, H. (1995). The effects of team loyalty and selected stadium factors on spectator attendance. Journal of Sport Management, 9, 153-172.

Walter, U., Edvardsson, B., \& Öström, A. (2010). Drivers of customer's service experiences: A study in the restaurant industry. Managing Service Quality, 20, 236-259.

Young, C., Cunningham, L., \& Lee, M. (1994). Assessing service quality as an effective management tool: The case of the airline industry. Journal of Marketing, 2, 76-96.

Zeithaml, V., Parasuraman, A., \& Berry, L. (1985). Problems and strategies in services marketing. Journal of Marketing, 49, 33-46. 